\title{
Correction
}

Monatsschr Kinderheilkd 2017 · 165:1120 https://doi.org/10.1007/s00112-017-0400-3

Online publiziert: 15. November 2017

c) Springer Medizin Verlag GmbH 2017

CrossMark

\section{H. Ott}

Fachbereich Pädiatrische Dermatologie und Allergologie, Kinder- und Jugendkrankenhaus AUF DER BULT, Hannover, Deutschland

\section{Correction: Chronische Urtikaria im Kindesalter. Rationale Diagnostik und Therapie}

\section{Correction:}

Monatsschr Kinderheilkd 2017

https://doi.org/10.1007/s00112-017-

0273-5

Im oben genannten Beitrag ist leider ein Fehler unterlaufen. Auf S. 444 steht im 2. Absatz unter der Zwischenüberschrift Omalizumab:

„Omalizumab wird unabhängig von Körpergewicht oder Serum-IgE-Spiegel 4-wöchentlich zusätzlich zur nsH1-AH-Gabe in einer Dosierung von $300 \mathrm{mg}$ vornehmlich in den M. deltoideus injiziert.“

Der Satz sollte lauten:

„Omalizumab wird unabhängig von Körpergewicht oder Serum-IgE-Spiegel 4-wöchentlich zusätzlich zur nsH1-AH-Gabe in einer Dosierung von $300 \mathrm{mg}$ vornehmlich subkutan im Bereich des M. deltoideus injiziert.“

Wir bitten Sie, die korrekte Version zu berücksichtigen und den Fehler zu entschuldigen.

\section{Korrespondenzadresse}

\section{PD Dr. H. Ott}

Fachbereich Pädiatrische Dermatologie und Allergologie, Kinder- und Jugendkrankenhaus AUF DER BULT

Janusz-Korczak-Allee 12, 30173 Hannover, Deutschland

ott@hka.de 